\title{
Addressing inequality? Economic affirmative action and communal capitalism in post-coup Fiji
}

\author{
Steven Ratuva
}

\section{Introduction}

Economic affirmative action, defined as 'government-mandated preferential policies toward government-designated groups' (Sowell 1990:10), became an important state policy in Fiji after independence in 1970. Economic affirmative action emerged as a result of growing concern about imbalances between Fiji's two principal ethnic groups, which was the result of the unequal process of capitalist development in the colonial economy in general, and the agricultural sector in particular (Narayan 1984; Overton 1988). However, it was not until after the 1987 military coups that the term 'affirmative action' began to be widely used in government circles. In the period since 1987, economic affirmative action has come to occupy a prominent place in Fiji's political discourse, being seen as an imperative for post-coup national reconstruction. Moreover, economic affirmative action is now commonly seen as an embodiment of 'progressive' ethnic Fijian thinking. This represents a change in perspective. Previously, economic affirmative action was associated with the more conservative 'paramountcy of Fijian interests' perspective (Durutalo 1986). This latter approach to economic affirmative action was 
embedded in the abrogated 1970 Constitution, as well as in colonial and post-colonial legislation relating to both land and aspects of ethnic Fijian culture. Given its pre-independence origins, it was concerned with preserving the hegemony of essentially colonial values. This conservatism may appear to stand in contradiction with the progressivity currently associated with economic affirmative action, but, as we shall see later, the seemingly contradictory nature of the two perspectives can be synthesised into what I propose to call in this chapter 'communal capitalism'.

Economic affirmative action has been an integral component of conflict resolution, sustainable and equitable development, democratisation and human rights in many societies. This is because it purports to address the phenomenon of equality-or rather, its absence. At the level of abstraction, the term equality seems to be a simple one. However, when used to examine concrete phenomena in their social context it has been the target of semantic manipulation. It thus continues to be elusive (Faundez 1994:1). In the US, for example, conservatives oppose economic affirmative action, and especially the use of quotas, on the grounds that it is a form of 'reverse discrimination' with the potential to create a new 'victim class'.

American advocates of economic affirmative action on the other hand argue that it helps to redress the historically determined disadvantaged position of marginalised groups like AfricanAmericans. However, advocates are divided as to whether economic affirmative action should be based on class, using 'the poor' as the designated social category, or based on ethnicity (Kahlenberg 1996). Notwithstanding this division though it remains the case that in the US economic affirmative action is official policy in some states. A similar debate has been witnessed in South Africa, where economic affirmative action has become part of the broad post-apartheid process of national reconstruction and reconciliation (Adam 1997). As in parts of the US, in South Africa economic affirmative action is mandatory, under the Employment Equity Bill. A third example can be found in Malaysia, where economic affirmative action was an integral component of the New Economic Policy (NEP) of 1970. It was imposed by a regime with authoritarian tendencies, and was aimed at alleviating the poverty within the bumiputeras - ethnic Malays-which was a critical source of income inequality between ethnic groups in Malaysia (Emsley 1996). 
Key aspects of economic affirmative action debates found in the US, South Africa and Malaysia can be found in Fiji. There are two main strands to the debate on economic affirmative action in Fiji. The first is the nationalist position, which pushes for economic affirmative action policies to be specific to the indigenous people of the archipelago. This position has both conservative and progressive adherents, as noted above, and is embodied in the 1990 Constitution. The second is the liberal position, which opts for the application of economic affirmative action for those deemed to be disadvantaged, regardless of ethnicity (Citizens Constitutional Forum 1995). This position is reflected in the 1997 Constitution (Amendment) Act.

The nationalist position has dominated attempts to introduce economic affirmative action in Fiji. However, despite an increasingly ambitious expression of political will, especially during the immediate post-coup period, there is still no coherent economic affirmative action blueprint in Fiji. Instead, there are a number of individual statesponsored programs implemented by a number of institutions. In part, the lack of a coherent blueprint in Fiji for economic affirmative action may be because it cannot be justified on the grounds of political powerlessness. Like South Africa and Malaysia, but unlike the US, the ethnic Fijians who have been designated as the intended beneficiaries of economic affirmative action constitute both the demographic majority and the politically dominant ethnic and social group. The overriding objective of economic affirmative action when it has been designed to benefit a designated group which is politically dominant has been to address historically-determined socioeconomic disparities. This is the case in Fiji. Economic affirmative action in Fiji has been designed to redress socioeconomic imbalances between ethnic Fijians and other ethnic groups found in the country. This justification has however been increasingly called into question in South Africa and Malaysia, as well as in the US, because many economic affirmative action programs have in fact largely benefited those who least need them: the middle class of the designated ethnic categories.

This chapter will similarly call into question the benefits of economic affirmative action in Fiji. The chapter begins by examining the origins of what I term communal capitalism. It continues by providing an analysis of the economic affirmative action intended to benefit ethnic Fijians in the wake of the 1987 coups. The chapter will then offer a case study of communal capitalism, using the Fijian 
Holdings Company Limited (FHC) as its source material. The reason for choosing the FHC is because, as the flagship for ethnic Fijian communal investment, it has been seen by many in Fiji as a success story in as far as communal capitalism is concerned. Be that as it may, it manifests some fundamental contradictions, which I will explore in this chapter.

\section{Economic affirmative action and communal capitalism}

Before and immediately after independence two seemingly contradictory positions were articulated in relation to the protection and enhancement of ethnic Fijian rights. The first was the protection of colonially inherited neotraditional institutions. This focused on preserving the vestiges of the colonial Native Policy, which was responsible for the marginalisation of ethnic Fijians from mainstream economic transactions. The second was the encouragement of ethnic Fijian participation in commerce. This focused on creating institutions that would be the guardians of ethnic Fijian commercial endeavours.

The 1970 Constitution contained provision for the protection of ethnic Fijian rights, but this was limited to preserving existing institutional arrangements such as the Native Lands Trust Board (NLTB), the Fijian Affairs Board (FAB), the Great Council of Chiefs, the Fijian Development Fund, the Native Land and Fisheries Commission, and the Agricultural Landlord and Tenants Ordinance of 1967, which was transformed into the Agricultural Landlord and Tenants Act in 1977. In that these institutions had originally been set up to sustain the communalistic 'divide and rule' philosophies of the colonial Native Policy, which excluded most ethnic Fijians from wider politics, the maintenance of these institutions in the immediate post-independence period had the direct role of consolidating and legitimising the postcolonial state-chiefly class alliance. This alliance constructed a new form of hegemony that continued to keep most ethnic Fijians within a constricted, 'protected' political space, and served, to use Gramsci's (1971) terminology, as a 'historic bloc' in Fiji (Durutalo 1986; Akram-Lodhi 1997).

Paradoxically, this institutionalised neo-colonial hegemony was to be the facilitating mechanism and guardian for ethnic Fijian participation in commerce. In the early post-independence period, an institution of neo-colonial hegemony - the Provincial Councils- 
served to promote economic affirmative action in Fiji. The Provincial Councils are a semi-state and semi-traditional administrative system with direct links to the FAB and the Great Council of Chiefs. The Provinces themselves are largely subsistence rural economies. Beginning in the 1970s Provincial Councils formed companies and invested in local or foreign corporations. As a form of economic affirmative action, the entry of the Provinces into capital and product markets was based on the neoclassical theory of 'trickle-down': that with sound investment and good businesses, the benefits of development would filter down to ordinary ethnic Fijians. In order to be able to pursue economic affirmative action, however, the Provincial Councils had to bridge the divide between the capitalist logic of accumulation and the need to maintain the hegemony of the statechiefly class alliance. In order to do this, resources for investment were mobilised through an appeal to a communal sense of obligation to the vanua.

Vanua refers to the relationship between the land and the people indigenous to the land. Critically, this relationship is symbolised by chiefly power: the chief 'owns' the land and 'owns' the people. The relationship has both political and spiritual dimensions, and is thus intensely ideological. It can however have a material impact. In making an appeal for investable resources to a communal sense of obligation to the vanua, capital is ideologically conceptualised as a collective entity belonging to the vanua. It is this conceptualisation which inspires the altruism witnessed in soli vakavanua, or community collection: money is mobilised through neotraditional festivals in which various tribal units compete. Indeed, tribal competition becomes an end in itself, because winning, and the publicity generated by winning, becomes a source of pride for the vanua. As a result, Provinces are continually engaged in competition over their soli vakavanua.

However, for the members of the vanua competition is a rivalry over the accumulation of social assets such as prestige, rather than the accrual of capital for investment in the market. Similarly, the ownership of a company that can result from soli vakavanua is not seen as a means towards accumulation but as an expression of political prestige for the vanua and its symbolic representation, the chief. Indeed, there is a painful psychological sanction in a failure to mobilise resources: it is an insult to the vanua, the chief and to ethnic 
Fijians themselves. The significance of capital as an accumulative factor of production is thus subsumed within a communal obligation to the vanua, and capital becomes an expression of a hegemonic collective identity rather than individual enrichment. Recall however that the vanua is symbolised by chiefly power. Capital may be ideologically conceptualised as belonging to the vanua, but the chiefs symbolise the vanua, 'owning' the land and the people. Therefore, in the various investments made by the Provincial Councils, chiefs were often made the legal holders of shares, the legal holders of company titles, and the directors any companies that were created. The result was the creation of a hybrid form of capitalist relations, based on the communal mobilisation of resources to collect capital for investment in enterprises, but often with the chiefs in formal legal control of that which has been invested: primordial servitude had been adapted to modern commercial exploitation. This is communal capitalism.

This form of communal resource mobilisation has contributed to the failure of many commercial enterprises organised on behalf of ethnic Fijians. Simply put, investments have not been based on commercial principles, and thus many of the enterprises arising out of such investments have been unable to compete in market relationships. Moreover, even when enterprises have been able to compete, the downside of such investment has been significant and perhaps unacceptable risk. As an example, in the 1970s the three Provincial Councils of Cakaudrove, Bua and Macuata formed a company called CBM Holdings, which operated a diverse investment portfolio. CBM Holdings bought shares worth 2.5 per cent of a major local company, Stinson and Pearce Limited, owned by a Euro-Fijian who was a former Alliance Party Minister of Finance. CBM Holdings' large investment left it exposed to significant risk, and when Stinson and Pearce was eventually closed, leaving behind a F $\$ 12$ million debt to the National Bank of Fiji, CBM Holdings lost a lot of money. This was not the only case in which CBM Holdings' exposure to risk resulted in losses: its investment of $\mathrm{F} \$ 150,000$ in the Ferry Freights Company was lost. Cakaudrove, Bau and Macuata were not alone in making such investments. Tailevu, Rewa, Lau, and Kadavu all had investment arms. Many of these investments were in areas that were highly competitive, such as retailing, commercial agriculture, transport and shipping, and where, as a result, rivalry was fierce and the risks involved were great. Moreover, the investments were often in 
activities that tended to be dominated by Indo-Fijian business. The failure of many of these investments has been translated by some into an inappropriate ethnic stereotype: namely, that ethnic Fijian culture is not conducive to free enterprise. This stereotype has served to undermine the genuine efforts of many ethnic Fijian entrepreneurs.

Ethnic Fijian entrepreneurship grew in the post-independence period. Over the three decades preceding 1986 the number of ethnic Fijians in business increased dramatically (Hailey 1986:4). Most of these were small-scale businesses in the informal sector that survived without state subsidy on a day-to-day basis and which generated income for a family unit. Despite this increase in informal small-scale entrepreneurship however there was a marked absence of ethnic Fijians from the formal and the large-scale business sector. In June 1987, for example, of the 700 companies listed by the Registrar of Companies, the ethnic ownership pattern was 50 per cent Indo-Fijian; 15 per cent ethnic Fijian; 20 per cent other; and 15 per cent joint venture between ethnic groups (Fiji Office of the Registrar of Companies 1987). Little appears to have changed in the decade since 1987. In 1997, of the 101 local companies registered under the Tax Free Zones policy, less than 10 per cent were owned by ethnic Fijians (Fiji Trade and Investment Board 1997).

Moreover, most ethnic Fijian businesses have been concentrated in the urban areas. Rural areas remain largely untouched. Thus, a survey done in 1995 by the Ministry of Fijian Affairs (MFA) showed that some 62 per cent of rural ethnic Fijians survived by participating in subsistence agriculture. Of those who earnt wages, 22 per cent relied upon agriculture as the source of their income and some 10.6 per cent were in non-agricultural paid employment. Only 4 per cent earnt their livelihood in retail trade and services (MFA 1995:64). Indeed, part of the reason for the perpetual underdevelopment of the rural economy may have to do with the drain of valuable family resources, as a result of the material impact of the soli vakavanua, to sustain an exploitative communal capitalist system.

The system was exploitative in the sense that the revenues generated from these businesses were not equitably distributed. The institutionalisation of communal resource extraction reproduced the poverty and perpetual marginalisation of many ethnic Fijians: there was no 'trickle down'. The contradiction is that personal and family savings that could have been used for daily sustenance and local 
investment were controlled by dominant state and chiefly élites to sustain an agenda which formally fulfilled the imperative of economic affirmative action but which in reality fulfilled the economic aspirations of élite ethnic Fijians. Thus, the resources mobilised through soli vakavanua were passed on through chiefs to Provincial bureaucrats and then on to Provincial companies, which then worked out the investment technicalities with the relevant financial institutions and authorities 'on behalf' of the people of the provinces. In the case of the business activities of the Provincial Councils, a substantial amount of any surplus that was generated was used to finance the administrative operation of the Provincial Councils: it thus served to sustain an ethnic Fijian bureaucratic strata. It was not distributed as dividends to individual ethnic Fijians, which would be normal investment practice, and which might have assisted in the alleviation of rural poverty. Moreover, many of these Provincial Council companies over the years formed partnerships, based on political cronyism and economic expediency, with foreign companies with interests in logging, hotels, and other resource-based sectors. I have already noted however that within these companies the chiefs were usually the legal holders of shares and company titles. Thus, using Provincial Council companies, some chiefs were able to acquire considerable personal benefit through the accumulation of wealth, while foreign and local non-ethnic Fijian companies benefited through political security and ready access to natural resources. The results were clear: during the 1970 s and early 1980 s communal capitalism clearly benefited the ethnic Fijian élite, whether it was entrenched within the state or the vanua. Moreover, the logic of communal capitalism served to reproduce the conditions of the colonial Native Policy; ethnic Fijians remained locked into a communal existence predicated upon chiefly hegemony.

In light of the widespread failure of many ethnic Fijian enterprises other than those operating in the informal sector through the 1970s and the 1980s, and the state's inability to create an institutional framework which would foster profitability amongst ethnic Fijian business, the need to consolidate an ethnic Fijian bourgeois class to complement both the chiefly élite and the ethnic Fijian bureaucratic strata since the military coups of 1987 became an increasingly urgent political priority. The Minister for Trade and Commerce suggested that 'Fijian society must be prepared to accept changes if our people are to 
become part of the mainstream of the economic life of our country' (Fiji Times, 11 January 1990). This advice was consistent with postcoup plans that sought to promote economic affirmative action amongst ethnic Fijians. These plans had two general characteristics. The first was to enable ethnic Fijians to engage in a wider and deeper range of market activities. The second was to dispel the stereotypic myth, reproduced over the years, that ethnic Fijians were not culturally induced towards private enterprise. Thus, economic affirmative action was tied to an expression of a modernist, 'progressive' ethnic Fijian identity.

The Nine Points Plan was drawn up in 1988 by a group of ethnic Fijian intellectuals, professionals and bureaucrats who came together in an umbrella body called the Fijian Initiative Group. Its explicit purpose was to promote economic affirmative action in favour of ethnic Fijians. It recommended: that $\mathrm{F} \$ 20$ million in equity be injected from the FAB to the FHC; that a unit trust for ethnic Fijians be established; that a compulsory savings scheme for ethnic Fijians be created; that government concessions to ethnic Fijian businesses be enhanced; that a Management Advisory Services Department be established within the FAB; that ethnic Fijians be allocated a minimum ownership of resource-based industries; that certain sectors of the economy be reserved for ethnic Fijian investment; that a daily newspaper be owned by ethnic Fijians; and that the FAB be restructured and strengthened (Fijian Initiative Group 1988).

Clearly, the proposals were far-reaching. In response to the proposals, the government allocated a $\mathrm{F} \$ 20$ million grant to the $\mathrm{FHC}$ from the FAB. The Fiji Development Bank (FDB), a parastatal, bought shares in an ethnic Fijian-owned daily newspaper. A review of the structure of the FAB made recommendations to make it both more independent of the MFA and make it more responsive to changes within the ethnic Fijian community. Finally, the Interim Government also approved the compulsory savings concept, although it has yet to be implemented.

However, the Nine Points Plan failed to deal with two key issues that have surrounded attempts to promote economic affirmative action within the ethnic Fijian community. The first issue has to do with the failure to systematically and objectively identify what constituted the 'designated group' to benefit from economic affirmative action. The new 1997 Constitution is vague, referring to 'all 
groups or categories of persons who are disadvantaged'. Even Section 21 of the 1990 Constitution, the strongest articulation of the nationalist view on economic affirmation action, vaguely designated 'Fijians and Rotumans' to be the designated group, stating that

parliament shall, with the object of promoting and safeguarding the economic, social, educational, cultural, traditional and other interests of the Fijian and Rotuman people, enact laws for those objects and shall direct the Government to adopt any program or activity for the attainment of the said objects and the government shall duly comply with such direction.

Section 21 was based on Article 153 of the Malaysian Constitution, which vests power in the Yang di-Pertuan (President), acting on behalf of the Cabinet, to safeguard 'the special position of the Malays'. What Section 21 clearly fails to do is to engage with the complicated constitutional debate concerning who exactly is a 'Fijian' (Robertson, this volume).

The second issue concerns the continuing inability of advisory reports and policy makers to institute relevant and appropriate programs which ensure an efficient return on the capital invested as a result of economic affirmative action. In post-independence Fiji attempts at economic affirmative action in favour of ethnic Fijians has resulted in unsustainable waste. Two examples will suffice: the Commercial Loans to Fijian Scheme (CLFS); and the Equity Investment Management Company Limited (EIMCOL) general store scheme of the FDB. The CLFS was specifically designed to create a class of indigenous Fijian entrepreneurs. However, failure to repay both interest and principal was so common that a number of loan portfolios within the CLFS were suspended, including loans for real estate and transport. By 1996 some F\$70 million worth of CLFS loans remained outstanding (FDB 1996). The EIMCOL scheme was established to train general store managers, who were also to be provided with loans for the purchase of a general store by the FDB. However, the performance of the EIMCOL general stores was very poor; all the EIMCOL general stores have either been closed or sold.

These failures were not addressed in the follow-up to the Nine Points Plan. Laisenia Qarase, the former Managing Director of the FDB, and a leading proponent of 'progressive' ethnic Fijian economic affirmative action, suggested that the objective of such action 'should be the achievement of overall parity between Fijians and other 
communities in all spheres of activities within the shortest period of time possible' (Qarase 1995:4). In a proposal entitled Ten Year Plan for Fijian Participation in Business, carried out under the auspices of the United Nations Economic and Social Commission for Asia and the Pacific, Qarase put forward five proposals to be carried out by the government to 'ensure that indigenous Fijians achieve 50 per cent ownership of the corporate sector and other business sectors by the year 2005' (Qarase 1995:2). The five proposals were: the enactment of appropriate legislation with the object of promoting and safeguarding the interest of ethnic Fijians; the reorganisation and strengthening of the ethnic Fijian administration; the accumulation of savings by ethnic Fijians to provide investment capital; the encouragement of ethnic Fijian investment; and the development of ethnic Fijian entrepreneurship, business education and training.

Both the Ten-Year Plan for Fijian Participation and the Nine Points Plan heavily drew upon the Malaysian NEP. This is especially apparent in relation to the proposal to establish a definitive timetable within which 50 per cent of the economy would come under ethnic Fijian ownership. As such, like the Malaysian policy, the plans represented attempts at social engineering. However, the uncritical introduction of the Malaysian model into the Fiji context can be questioned. The NEP has had some unfavourable consequences that must be acknowledged, as they could be replicated. Economic affirmative action in Malaysia has reinforced ethnic segregation; consolidated a small but disproportionately powerful indigenous bourgeoisie which operates in conjunction with foreign capital and which survives on state patronage; worsened disparities in the distribution of wealth amongst ethnic Malays; and created unhealthy competition within the designated group itself (Gometz 1994). It can also be noted that the provision of a timetable in Malaysia has not worked (Emsley 1996).

Both plans can also be questioned for what they attempt to do. In their emphasis on enhancing the size of investments made within the ethnic Fijian community, they sought to foster large-scale, capitalintensive growth directed by ethnic Fijians. In part, this was probably due to the marked absence of ethnic Fijians from high profile corporate activity, as we have seen. However, in following such a strategy, embourgeoisement was the centripetal focus of the government's economic affirmative action-as in Malaysia. The economic leverage of the ethnic Fijian chiefly and bureaucratic strata were thus to be enhanced. 
This can clearly be seen by some of the criteria that were used to judge the effectiveness of economic affirmative action. The FDB, one of the sponsors of the two plans, has, during the early 1990s, been using the size of loans disbursed to ethnic Fijians as a criteria to measure the 'success' of its economic affirmative action programs (FDB, various issues). As in the past, the rate of return on the investment was not a critical variable in judging success. In that the FDB is a parastatal, such an approach to lending demonstrates state intervention to carve out an economic space for élite ethnic Fijians within the economy. The number of ethnic Fijians eligible for large loans was obviously limited; the scope for patronage is thus clear. Indeed, ethnic Fijian élites made it a point to be seen to be actively promoting large ethnic Fijian businesses, in an effort to win political legitimacy. Ironically, such a policy, in not letting resource allocation take place through the market, ran counter to the economic liberalisation policies of the state (Sutherland, this volume).

The pursuit of large investment by the ethnic Fijian élite that benefited from communal capitalism paradoxically undermined and marginalised

very small informally-operated (ethnic Fijian) businesses, including people who sold cordial and home-made sweets outside urban schools, prepared cooked food for wharf and factory workers, operated grass-cutting contracts and sold in the municipal markets (Chung 1989:193).

So too did the failure of the two plans to make recommendations designed to assist the development of ethnic Fijian entrepreneurial skills. Indeed, a critical area where the plans departed from the Malaysian NEP was the failure to couple embourgeoisement with poverty alleviation. The two plans did not present an alternative development paradigm suitable to the socioeconomic conditions and limited resources of the majority of ethnic Fijians, and especially the economically marginalised. This is not surprising. Economic affirmative action through communal capitalism merely served to reproduce the conditions of the colonial Native Policy, in which ethnic Fijians were locked into a communal existence under chiefly hegemony. It is not 'progressive', it is conservative, and this helps explain why a key role of economic affirmative action has been its use as an instrument of ethnically based political mobilisation by ethnic nationalists and the traditional aristocracy seeking to defend of the 
status quo (Prasad, this volume). However, the ethnic Fijian élite was not the only beneficiary in this structure. By endorsing, in the guise of economic affirmative action for ethnic Fijians, orthodox investment strategies that had proven wasteful and unsustainable in the past, the non-ethnic Fijian bourgeoisie-both local and foreign-had their economic dominance within the economy reinforced.

Although it appears to be a particular-and peculiar-kind of entrepreneurial strategy, communal capitalism is more: it has a deeper structural form which incorporates ethnic Fijian communal obligations, chiefly authority, and collective investment. It is thus an adaptation of ethnic Fijian 'tradition' to the demands of the market that simultaneously serves to reinvent what had been colonial paternalism. It is perhaps this adaptation which serves to give it such clear ideological power. Moreover, despite the entrepreneurial failures of communal capitalism, it has continued to be the only economic strategy that enables the continued enrichment of the ethnic Fijian élite. It is in this that it is possible to witness the fundamental contradiction of communal capitalism: communal capitalism has retarded the development of a vibrant ethnic Fijian bourgeoisie because a lot of the capital available for investment and the energy needed for individual entrepreneurship has been 'collectivised' through communal investment, to the benefit of an élite bureaucratic and chiefly strata. That this is so in practice will be demonstrated in the next section, where a case study of the flagship of communal capitalism, the FHC, is presented.

\section{The FHC and communal capitalism}

As already noted, the Nine Points Plan argued in favour of enhancing the equity of the FHC. Although it pre-dates the coups, and thus the deepening of the discourse around economic affirmative action, the FHC is nonetheless modelled on the Malaysian bumiputera investment body, Permodalan National Berhad. However, the principle underlying the FHC is that of communal capitalism. The FHC was incorporated in December 1984, and was a creation of the Great Council of Chiefs. Under the hegemonic guardianship of the Great Council of Chiefs the FHC was to symbolically represent the interests of ethnic Fijians. Thus, the investment mandate of the FHC, as outlined in its corporate plan, was 'to increase Fijian participation in 
the commercial economy...through acquisition of equity in established, well-managed, profitable companies with excellent prospects for growth'. Moreover, the FHC was to ensure that the 'benefits spread as widely as possible among the Fijian people' (FHC 1994:1).

In keeping with communal capitalism, share holding was communal, being mobilised through the Provinces, through the NLTB, and through the FAB. When the FHC was incorporated resources worth $\mathrm{F} \$ 1,145,145$ were mobilised from the ethnic Fijian community for investment in it. Of this, $\mathrm{F} \$ 1$ million came from the Provinces, the NLTB and the FAB, who in turn received shares in the FHC. The FHC then used the same quantity of resources, $F \$ 1$ million, to purchase $1,000,000$ higher dividend ' $\mathrm{A}$ ' class shares in its first major investment, Basic Industries Limited. Proposals were then made for the FHC to expand its investment portfolio. The first proposal was that the FHC buy a majority holding in two companies, Fiji Industries Limited and Standard Concrete Industries Limited; both were owned by Basic Industries Limited. Thus, this implied increasing the share ownership of the FHC in Basic Industries Limited. The second proposal was that the FHC invest in Carlton Brewery (Fiji) Limited, an Australian transnational which produced Fiji Bitter, the market leader in the country. The FHC however lacked the resources needed to fund either proposal.

One possibility that was suggested was that the FDB act as a middleman, buying shares which would later be sold to the FHC. In the event, the Great Council of Chiefs agreed that the proposals represented a good way by which to expand the FHC. An action plan was drawn up by the board of the FHC, in response to the agreement of the Great Council of Chiefs. A key part of this action plan was the proposal to increase the share capital received from the Provincial Councils, the FAB, and the NLTB, in order to finance the acquisition of shares from both Basic Industries Limited and Carlton Brewery. It was proposed that $\mathrm{F} \$ 2$ million be raised to buy more shares in Basic Industries Limited, and that a further $\mathrm{F} \$ 4$ million be raised to purchase a stake in Carlton Brewery. Thus, the capital invested in the FHC rapidly increased from $F \$ 1$ million to $F \$ 5$ million.

With an expanded capital base, the FHC increased its portfolio of investments. For example, one of its early commercial ventures was to buy 50 per cent of the shares in Burns Philp, an Australian company with investments in shipping, brewing, agricultural production and agro-processing, and wholesale and retail trade. As a result the FHC 
grew quickly. In 1985, only a year after its creation, it paid its first dividend to its shareholders. Moreover, as the portfolio of investments held by the FHC expanded, so too did the dividends it paid out to its shareholders, barring the disruptions of the 1987 coups. By 1992, profit after tax had reached $\mathrm{F} \$ 2,752,554$.

In 1992, the FHC underwent a corporate restructuring when it went from being a public limited company to being a private limited company. By changing its status to that of a private company, the FHC hoped to facilitate an expansion of individual and private group investment through it, in the form of managed funds, and in so doing expand its investment portfolio. The FHC thus began to manage individual and group investment funds to a maximum limit of F\$10,000, to ensure that the 'benefits of Fijian Holdings' shareholdings are spread as widely as possible' (FHC 1993:7-8). To ensure that only ethnic Fijians were able to buy into these managed funds, individual purchasers were confined to those registered in the Vola ni Kawa Bula, the kinship and land ownership register which determines who exactly is an ethnic Fijian (Robertson, this volume). This shift in company status was significant: it indicated a recognition of the fact that economic affirmative action had to generate, in addition to communal benefits, benefits for individual ethnic Fijians. Given, however, that few individual ethnic Fijians had access to $F \$ 10,000$ it was in reality a recognition of the principle of embourgeoisement which, behind the rhetoric, underpinned much of the economic affirmative action taking place on behalf of the ethnic Fijian community.

The dramatic expansion of the FHC in the 1990 to 1994 period was not only a result of corporate restructuring; it was also a result of the F\$20 million interest-free loan provided by the government through the FAB in 1989 under the Nine Points Plan. In the wake of both this loan and the receipt of funds from individual and groups of ethnic Fijians, paid up capital grew from $\mathrm{F} \$ 1.2$ million in 1985 to $\mathrm{F} \$ 27.5$ million in 1994. Total assets rose from $\mathrm{F} \$ 1.3$ million in 1985 to $\mathrm{F} \$ 36.3$ million in 1994. The net value of assets increased from $\$ 170,248$ in 1985 to $\$ 3.2$ million in 1994 . During the 1990 s, the dividend paid to FHC shareholders was 20 per cent for those with ' $A$ ' shares and 5 per cent for those with ' $\mathrm{B}$ ' shares. However, in keeping with corporate practice, the ' $\mathrm{B}$ ' share dividend was paid into a sinking fund to meet the repayment obligations of the $\mathrm{F} \$ 20$ million loan received from the government through the FAB. 
In 1994 the FHC had interests in nine major companies in Fiji, worth $F \$ 27,111,948$. These were: Basic Industries Limited, which was 100 per cent owned by FHC; the Fiji Sugar Corporation, in which the FHC had a 13.2 per cent stake; the Fijian Property Trust, in which the FHC had an 89.7 per cent stake; Carlton Brewery (Fiji) Limited, in which the FHC had a 30 per cent stake; the Unit Trust of Fiji, in which the FHC had an 8.9 per cent stake; Motibhai and Company Limited, in which the FHC had 100 per cent of all preference shares; the Merchant Bank of Fiji Limited, in which the FHC had a 50 per cent stake; Carpenters Properties Limited, in which the FHC had a 50 per cent stake; and Goodman Fielder Watties, in which the FHC had 100 per cent of all preference shares. In 1995 these companies had profits of between $\mathrm{F} \$ 0.9$ million and $\mathrm{F} \$ 4$ million (FHC 1994; 1995).

Clearly, as an investment company equipped with an astute young management, the FHC has done relatively well, especially in comparison to the overall performance of the Fiji economy (Sepehri and Akram-Lodhi, this volume). However, as an institution created to economically advance the interests of ethnic Fijians, it is necessary to deconstruct the actual interests it represents by examining the distribution of share holdings in the FHC. Shareholders' names were last published in the 1992 Annual Report. That report shows the distribution of the outstanding 4,647,934 ' $\mathrm{A}$ ' class shares of the $\mathrm{FHC}$ to comprise: the NLTB (500,000 shares); the FAB (100,000 shares); the Provinces (713,650 shares); and private shareholders (3,384,034 shares). Each share is worth one Fiji dollar. Shares held by the NLTB, the FAB and the Provinces thus amount to about 27 per cent of FHC equity. The following sections examine each of these shareholders in turn.

\section{The NLTB}

The biggest single FHC shareholder, the NLTB was founded in 1940 to administer 'native land' which is communally owned by ethnic Fijians. Such land cannot be bought or sold; it can only be leased, for agricultural, commercial or residential purposes. Today, the NLTB administers about 83 per cent of the country's land. Of this, 420,000 hectares is leased out to 24,700 tenants in agriculture, commerce, industry, tourism, and public and civil projects. Royalties and lease monies from land are distributed by the NLTB in a way that reproduces socioeconomic inequality. The NLTB takes 25 per cent of land revenues for institutional maintenance, which in essence benefits 
the ethnic Fijian bureaucracy. Some 75 per cent is distributed to the landowners through the chiefs (Prasad and Kumar, this volume). It is common for the chiefs to receive the bulk of the money. The rest trickles down the ethnic Fijian social hierarchy, with individuals receiving amounts compatible with their social position.

As an investor and guardian of ethnic Fijian land, the NLTB's record leaves a lot to be desired. Over the years it has been rocked by financial scandals, charges of nepotism, cronyism and corruption (Fiji Times, 15 April 1996). Moreover, despite a 25 per cent charge for administering lease monies from a fixed asset and despite an annual government subsidy of F $\$ 1$ million, the NLTB has recorded losses since 1986 and the accounts have not been audited since 1991. The unaudited figures showed an operating deficit of $\mathrm{F} \$ 1.6$ million in 1992, a figure that seemed reasonably consistent over the previous few years (The Review, June 1997:19). At the end of 1993 the NLTB had an overdraft of $\mathrm{F} \$ 16.1$ million, with some $\mathrm{F} \$ 4.4$ million worth of cheques still pending presentation to the bank. By 1997 the NLTB was on the verge of bankruptcy.

The difficulties faced by NLTB are in part due to the extremely complex relationship between the state and the chiefs in financial affairs. This complexity can be illustrated by an example. In the 1980s F $\$ 1.7$ million of Australian overseas development cooperation money designed to enable ethnic Fijian landowners to participate in the timber industry was used to finance a company, Kubuna/Fiji Forest Industry (FFI) (The Review, June 1997). The FFI was a joint venture between CBM Holdings and Westralian Forest Industries, an Australian company. As we have already seen, CBM Holdings was an ethnic Fijian company 'owned' by the landowners of the three provinces of Cakaudrove, Bua and Macuata, but in reality controlled and run by chiefs and, in this instance, their foreign business counterparts. The company belonged to the lewe ni vanua, or people, of the Kabuna Confederacy, ${ }^{1}$ operating through their paramount chief, Ratu Sir George Cakobau, who was also both the highest traditional chief in Fiji and Fiji's Governor General. Moreover, in his capacity as Governor General, Cakobau was not only Head of State, he was also Chairman of the NLTB. In charge of the financial operations of the company was the General Manager of the NLTB, Josevata Kamikamica, a member of the Kubuna Confederacy and a subject of 
Cakobau. The Chairman of CBM Holdings was Ratu Sir Penaia Ganilau, the paramount chief of three provinces within the Confederacy, who would be the successor to Cakobau as both Fiji's Governor General and Chairman of the NLTB.

Clearly, huge potential conflicts of interest were witnessed in this business arrangement. Power to grant logging licences and concessions $^{2}$ on all native land is vested in the NLTB under the Native Land Trust Act. The FFI 'belonged' to the Confederacy of which the Head of State and the Chairman of the NLTB was the chief. The General Manager of the NLTB was a subject of the chief. The Chairman of CBM Holdings was the paramount chief of a component part of the Confederacy to which the Head of State and the Chairman of the NLTB was the chief. Thus, the power vested in the NLTB could give rise to a potential conflict of interest, as in the case of CBM and FFI. This is not to say that it did; merely to strongly stress that the complex political, communal and bureaucratic entanglement witnessed in the establishment of FFI is symptomatic of an NLTB corporate culture that makes it difficult to distinguish between purely market, purely communal, and purely personal interests. There are many other examples to support the premise that, under the guise of vanua or vakaturaga, interpersonal relationships can be the basis of decisions that are then legitimised within institutional structures. As a consequence, economic affirmative action for ethnic Fijian landowners has the potential to become a vehicle for the enrichment of companies acting in collaboration with strategically located chiefs, self-appointed ethnic Fijian leaders, and influential bureaucrats.

Given such an example, the NLTB's communal investment in the FHC needs serious scrutiny. The NLTB, given its history of financial scandals, does not have the institutional capacity to be able to appropriately scrutinise entrepreneurial investment, especially on behalf of ethnic Fijians, who themselves constitute a heterogeneous diffusion of class, tribal and political loyalties. Thus, the NLTB does not represent a homogeneous ethnic Fijian interest, despite official claims to the contrary. It represents a narrow parastatal, bureaucratic and private institutional interest, propagated as universally ethnic Fijian. The NLTB's shares in the FHC are an entrepreneurial engagement that advances this narrow interest. In so doing, the NLTB not only administers land, it also legitimises communal capitalism and 
chiefly hegemony. This will only be deepened if NLTB investments in the FHC are ploughed back into the institution. Such a strategy will reproduce the cycle of impotent investment that could instead be creatively deployed for poverty alleviation amongst ethnic Fijians.

\section{The FAB}

Established under the Fijian Affairs Act of 1940, the FAB has institutional and political control over the MFA, in order to ensure that the MFA promotes the well-being and proper government of ethnic Fijians. The MFA, which is directly accountable to the Cabinet and the FAB, and thus the Great Council of Chiefs, is, as a consequence of this line of authority, still anchored to chiefly authority and the political norms necessary to preserve that authority. In turn, the FAB is accountable to the Great Council of Chiefs. Thus, despite radical changes in the national and international political climate, both the MFA and the FAB are extremely conservative institutions. Nonetheless, both are important institutions in the lives of ethnic Fijians. The MFA is an important institution in promoting economic affirmative action, especially through its scholarship scheme which, despite problems, has been hailed as a success in creating a large group of educated ethnic Fijians.

In addition to the 100,000 ' $\mathrm{A}$ ' class shares already mentioned, the $\mathrm{FAB}$ has 20 million ' $\mathrm{B}$ ' class shares in the FHC. As noted above, each share is worth one Fiji dollar. The government provided the F $\$ 20$ million needed to make the investment under the Nine Points Plan. This is the largest single amount of money that has been disbursed for economic affirmative action. It was envisaged that being sold to ethnic Fijians over time would disperse the amount. However, this has not taken place. In this light, it can be argued that ordinary ethnic Fijians have not benefited. The FAB, by receiving dividends, has been a major beneficiary; this though serves the interests of the ethnic Fijian bureaucracy. There have been two other major beneficiaries of this investment. First, there have been those who already have shares in the FHC: the investment of the FAB serves to enhance the value of their holding. Second, there have been local and foreign corporations like Carlton Brewery and Motibhai and Company Limited, in which the FHC heavily invests, and which stand to gain from the FHC having a larger market capitalisation. In both cases, ordinary ethnic 
Fijians at best stand to make only a peripheral gain. Moreover, in that the investment of the FAB in the FHC came from the government, FHC investors and investments are in fact being indirectly subsidised by the state through its efforts to promote economic affirmative action.

\section{The Provincial Councils}

As has already been discussed, the Provinces are a mixture of state and traditional administration. Investible resources are extracted as a consequence of the obligation of ethnic Fijians to the vanua and to the chief. Chiefly authority is usually used to collect quotas such as $\mathrm{F} \$ 1,000$ per tokatoka, or extended family, or $\mathrm{F} \$ 15,000$ per village. The quotas are however arbitrarily imposed by Provincial bureaucrats using the authority of the chiefs. With minimal sources of income, villagers expend labour and time collecting money in an effort to accrue social assets, even at the price of their own domestic poverty.

All fourteen Provinces have shares in the FHC. If we crudely allocate the distribution of shares equally amongst the Provinces, there would be about 50,000 per province. If we crudely allocate the distribution of shares equally amongst ethnic Fijians, there would be 1.68 shares per ethnic Fijian. Even if we crudely allocate the distribution of shares equally amongst the rural ethnic Fijian population, there would still only be 2.84 shares per rural ethnic Fijian. These are very low allocations, given that each share is worth one Fiji dollar and given that individual donations to communal collections are often larger by a factor of ten. The figures don't add up, and from the point of view of the return on the investment, undoubtedly individual ethnic Fijians would have been better off keeping their donations to communal collection and investing it themselves. The meagre return from the investment of the Provinces is because the dividends paid by the FHC have been used mostly to sustain the Provincial institutions and the privileges of individuals and groups who have direct access to Provincial institutions. Such is the degree of absurdity of communal capitalism.

\section{Private companies and small groups}

Private companies and small groups such as tikina, or districts, and mataqali, or land-owning units, possess about 72 per cent of the shares of the FHC. However, most of the private companies who own shares in the FHC are owned by individuals or groups of individuals who are 
established business people, professionals or bureaucrats. Given ethnic restrictions on the ownership of shares in the FHC, they are clearly owned by the ethnic Fijian élite. In 1992 only about 30 companies which were kin or community-based owned shares in the FHC (FHC 1992).

It has already been noted that the change in status of the FHC from a public company to a private company was officially justified on the basis that the change in status would extend the benefits of the FHC to as wide a group of ethnic Fijians as possible. This justification was disingenuous. The change in the status of the FHC was primarily a result of lobbying by the ethnic Fijian élite who dominate its private company share ownership, and who wanted greater control over their investment and the dividends that it paid. Moreover, this emerging ethnic Fijian bourgeois class has found a new ally: with the foreign and local non-ethnic Fijian bourgeoisie in whose companies the FHC has purchased equity. Thus, the new ethnic Fijian bourgeoisie has been able to use economic affirmative action policies in order to promote its own interests through state-subsidised capital accumulation. This is consistent with a long-standing aim of post-coup governments in Fiji to create an ethnic Fijian bourgeois class rooted in the market-driven logic of capital accumulation.

This aim has not gone uncontested. There has, for example, been growing criticism that economic affirmative action has favoured certain individuals from certain Provinces. Most of the private company and small group shares in the FHC are from the Provinces of Kadavu, Lau and Lomaiviti, all outlying archipelagos (FHC 1992). Thus, many of the Provinces are not represented in the emerging ethnic Fijian bourgeoisie. This is a potential cause of inter-provincial dispute. Moreover, there has been public controversy about whether some of the individuals who have invested in the FHC have been engaged in insider trading. Some individuals have shareholdings that exceed those of their Province. Given the influence and professional skills of some within the emerging ethnic Fijian bourgeoisie, it is possible that they have been able to monopolise access to information about the FHC, and this has raised questions about commercial ethics and personal credibility (Korovulavula 1994). However, these criticisms have not extended to the implicit principle underlying much government action to promote economic affirmative action since the coups: the need to create an ethnic Fijian bourgeoisie. 


\section{Conclusion}

The FHC is undoubtedly a successful private company. However, it does not represent a successful example of either the entry of ethnic Fijians into business or of economic affirmative action. Capital accumulation in market economies is ultimately determined by the forces of market, even if those forces are regulated by the state, and not by the ethnic identity of the market participant. Economic affirmative action interacts with this dynamic. In Fiji, the interaction between economic affirmative action and accumulation has been problematic. Part of the problem has been an inability to precisely define the group designated to receive economic affirmative action: who exactly is an ethnic Fijian? Part of the problem has been the unimaginative and uncritical way in which economic affirmative action strategies were imported from Malaysia and not based upon the socioeconomic position of ethnic Fijians.

More fundamentally, economic affirmative action through the activities of institutions such as the FHC has had a questionable impact upon the majority of ethnic Fijians. The FHC is an example of economic affirmative action that serves to reproduce what has been termed in this chapter communal capitalism. Communal capitalism has resulted in institutions such as the NLTB, the FAB and the Provincial Councils all becoming directly involved in commerce and investment, with often poor economic results. Communal capitalism has however served to reproduce the exploitative hegemony of a minority of ethnic Fijians within the state-chiefly alliance, and in so doing maintained the broad outlines of colonial Native Policy. Communal capitalism, and the need for resources that it entails, becomes an arena for economic and political mobilisation of ordinary ethnic Fijians by an élite concerned with sustaining its own economic and political hegemony. Meanwhile, poverty amongst ethnic Fijians deepens (Sepehri and Akram-Lodhi, this volume). Such an outcome is a consequence of the fact that the benefits of economic affirmative action have been concentrated in the hands of a few: state bureaucrats, chiefs, the foreign and local non-ethnic bourgeoisie, and the emerging ethnic Fijian bourgeois class.

The future of economic affirmative action in Fiji had come increasingly into conflict with the economic liberalisation policies of the previous government. The reason was obvious: liberalisation must ultimately threaten state policies that seek to grant ethnically based 
preferences. In this light, the state in the post-election period faces two clear challenges. The first is that the state will need to respond to the climate of globalisation. Despite the clear victory of the Fiji Labour Party in the 1999 general elections, it is entirely possible that as a result of multiparty government the state will do this by maintaining as close an affinity as possible to the policies of the International Monetary Fund and the World Trade Organization. The second challenge faced by the state is that it will need to try and accommodate the political impact of the nationalist constituency, which policies of economic affirmative action have sustained. Given the contradictions of economic affirmative action discussed in this chapter, and the limited capacity of the state apparatus in Fiji, whether these two challenges can be met is an open question.

\section{Endnotes}

1. A number of Provinces make up a Confederacy (matanitu). There are three main Confederacies in Fiji: Kubuna, Tovata and Burebasaga. These Confederacies are based upon traditional alliances between tribal polities, and have their roots in precolonial attempts to form centralised governments in Fiji by early European settlers and chiefs. Presently, Confederacies act as means of ceremonial and traditional mobilisation. In a way, the political loyalty of ethnic Fijians is diverse: they have loyalty to various levels of tribal categories, loyalty to the Confederacy and loyalty to the state.

2. The granting of logging licences by the NLTB does not require the consent of the members of the landowning unit, but, if deemed necessary, the NLTB will carry out consultation with the landowners. A concession, on the other hand, is also a licence but is 'granted over a large area, usually to a major logging company, and over land owned by many owning units, and for a longer period than a standard licence' (NLTB, nd:2). 
This text is taken from Confronting Fiji Futures, edited by A. Haroon Akram-Lodhi, published 2016 by ANU eView, The Australian National University, Canberra, Australia. 